\title{
AN EVALUATION OF VENDOR MANAGED INVENTORY PRACTICES FROM SMALL AND MEDIUM INDIAN ENTERPRISES
}

\author{
Lixin Shen ${ }^{1}$, Kannan Govindan ${ }^{2}$, Atul B. Borade ${ }^{3}$, \\ Ali Diabat ${ }^{4}$, Devika Kannan ${ }^{5}$ \\ ${ }^{1}$ Transportation Management College, Dalian Maritime University, Dalian, China \\ ${ }^{2}$ Department of Business and Economics, University of Southern Denmark, Odense, Denmark \\ ${ }^{3}$ Department of Mechanical Engineering, Jawaharlal Darda Institute \\ of Engineering and Technology, India \\ ${ }^{4}$ Department of Engineering Systems \& Management, Masdar Institute \\ of Science and Technology, Abu Dhabi, United Arab Emirates \\ ${ }^{5}$ Department of Mechanical and Manufacturing Engineering, \\ Aalborg University, Copenhagen, Denmark \\ e-mail:2gov@sam.sdu.dk (corresponding author)
}

Received 19 July 2012; accepted 12 November 2012

\begin{abstract}
Vendor managed inventory has proven to be an effective tool for improving the supply chain performance by decreasing inventory-related costs and increasing customer service. It is quite evident from the literature that vendor managed inventory (VMI) has been successfully implemented in small and medium enterprises (SMEs). However, studies related to the implementation of VMI in Indian SMEs are very limited. Therefore, this study presents an empirical investigation of VMI practices in Indian SMEs using survey methodology. The paper evaluates the benefits, barriers, and effects of adopting VMI in Indian SMEs, and also investigates the IT tools and software used for VMI adoption. Furthermore, this study explores the dissimilarities among various sectors of SMEs adopting VMI. Based on the proposed methodology, it is found that organizational issues and unwillingness to share information are the major barriers. In terms of benefits, the major influencing variables are improved efficiency and improved channel relations.
\end{abstract}

Keywords: vendor managed inventory, Indian SME's, benefits,operational issues, barriers, factor analysis, IT tools.

Reference to this paper should be made as follows: Shen, L.; Govindan, K.; Borade, A. B.; Diabat, A.; Kannan, D. 2013. An evaluation of vendor managed inventory practices from small and medium indian enterprises, Journal of Business Economics and Management 14(Supplement 1): S76-S95.

JEL Classification: C38, L29, L60, L80.

\section{Introduction}

India is showing continuous growth in its absolute gross domestic product. The increased growth is due to a revival in the manufacturing sector, to faster growth in the service sector, and to bigger foreign investments. As a result, the numbers of SMEs 
have increased and are playing a vital role in India's growth (Simoni et al. 2010). Indian companies have also realized the importance of collaborative supply chain management (SCM). SCM practices are constantly evolving and changing in response to strategic changes in the firm, changes in technology, competitive actions, and supplier and customer demands (Khan, Pillania 2008). One such evolution is vendor managed inventory (VMI). VMI is an alternative to traditional order-based replenishment practices. VMI gives the supplier both responsibility and authority to manage the entire replenishment process. The customer company provides the supplier access to inventory and demand information and sets the targets for availability. Then the supplier decides when and how much to deliver (Kaipia et al. 2002).

A great deal of evidence has shown that the VMI approach can improve supply chain performance by decreasing inventory-related costs and increasing customer service. However, a supply chain is a complex system consisting of numerous interrelated channel entities, such as suppliers, intermediaries, third-party service providers, and final customers. These firms are connected by material, financial, and information flows that travel both directions along the supply chain. As such, despite the growing popularity of VMI, implementing this approach can be more challenging and difficult in practice than what is perceived in theories, especially when the trust between supply chain members and their actual commitments are in question (Yu et al. 2009).

Three main types of contributions can be found in the VMI literature: general, case studies, and models. General papers give an overview definition of VMI and the main benefits of its application. Industrial case studies determine the boundaries of the VMI application, its benefits, and limitations. Papers on modeling propose mathematical models that underline key parameters that impact VMI performance. Researchers introduce VMI in general terms belonging to the concept family. The process terms are used in a majority of papers, but are less developed. The cooperation and technology sides are mainly treated in case studies. However, authors have their own interpretations of the integration of the cooperative process (Marquès et al. 2010). This paper focuses on the general and operational part of VMI. The literature has identified that each VMI project is unique owing to the following reasons:

1. Each industry has different resources, structure, and capability.

2. Products and processes in each industry differ.

3. The level of integration between supply chain members is different.

4. The strategic and operational objectives of every industry are different.

5. Regulations, policies, legal, and technical issues differ from country to country and from industry to industry.

Research on case studies and models do not address the above reasons. However, in case of implementation, the above reasons are crucial. Various authors agree that the issue is different for SMEs and large organizations. The present paper proposes to shed light on VMI practices in Indian SMEs. It tries to find answers to the following research questions from an Indian perspective.

R1: What are the most important results achieved through the use of VMI? What are the success drivers for establishing and maintaining VMI? 
R2: What are the difficulties and barriers experienced with the implementation of VMI?

R3: What are the production and data management systems needed to coordinate for smooth adoption of VMI?

R4: What is the method used for communication in VMI? How are the purchase orders and payment transactions done?

H0: R5: How do industries assure readiness for information sharing? What are the problems related to information sharing?

R5: What are the effects of adopting VMI on productivity, quality, cost, and service parameters?

The rest of the paper is organized as follows. Section 1 contains the literature review. It presents the various VMI-related research issues. Section 2 describes the methodology adopted for this study. Section 3 summarizes and discusses the results of the study. Finally, conclusions are drawn with future directions.

\section{Literature review}

A large literature is available on vendor managed inventory (VMI) studies. The literature could be categorized in numerous ways, but for simplicity we present the literature under four headings only. For more detailed review on VMI kindly refer to Govindan (2013).

\subsection{Determinants of VMI}

Dorling et al. (2005) identified key determinants of successful VMI. Determinants and strategic supply chain relationships were validated through action research, triangulation with prior literature, and case study findings from other industries and countries. Danese and Romano (2011) cautioned about the complexity of VMI systems for improving dynamics of a supply chain. Dong et al. (2007) pursued a different tactic from most of the previous research into VMI, and instead followed the technology adoption literature by examining the environmental determinants of VMI based on a mail survey. Marquès et al. (2010) explored physical and behavioral dimensions through a review of the VMI literature. Using this review, a global definition of the concept and the associated processes was built. Bhakoo et al. (2012) identified that most of the empirical studies addressing the issue of VMI have focused on manufacturing firms and retailers. The study investigated applications of vendor managed inventory systems in healthcare supply chains and found remarkable results.

The literature identifies the determinants of VMI implementation; however, it is difficult to find the conditions that call for VMI implementation, due to the fact that VMI is not only a strategic issue but is closely linked with the production system. In this study we use R3 to assist in the identification of production systems that would ease VMI implementations in an Indian context. 


\subsection{Character and universal applicability of VMI}

Most authors tend to consider VMI at the dyadic level, namely as an approach for managing materials and information flows between one or more customers and their immediate suppliers. However, Danese (2006) adopted a supply network perspective, and explained how VMI could be extended both upstream and downstream and considered the supply network as a whole rather than as a series of dyads. Zammori et al. (2009) attempted to develop general guidelines for VMI adoptions. In accordance with its operating aim, the paper briefly pinpointed the legal issues of the agreement, and focused on the technical features and service level agreements. Borade and Bansod (2010); Borade et al. (2012) carried out a study about VMI practices in an Indian context which investigated the differences among large and small industries. It was observed that adoption factors were different in large and small industries. Stanger et al. (2012) discussed the application of VMI in perishable supply chains. The possibility of application in U.K. blood supply chain was also discussed.

Current literature pinpoints the successful implementation of VMI among different industries in a number of countries. However, industry-specific and country-specific issues have not been largely addressed. This study seeks to find the influencing drivers and the most important results achieved through the use of VMI in Indian industries (R1).

\subsection{Information technology and VMI}

Information technology adoptions are widely seen in the literature. Whipple and Russell (2007) conducted exploratory interviews to better understand the characteristics of collaborative activities in today's supply chain environment. The study provided vital inputs on the VMI setting from retailer's and manufacturer's perspectives. Pero et al. (2010) posited that supply chain configuration and collaboration complexity increases the level of supply chain coordination complexity. In such an event, it is advisable to use practices and tools such as VMI or information sharing to achieve a higher level of collaboration and integration between client and suppliers. Olorunniwo and Li (2010) investigated the use of information technology (IT) and supply chain management initiatives and their impact on a company's performance in reverse logistics.

Other segments cover modeling and simulation studies (Thron et al. 2006; Achabal et al. 2000; Disney, Towill 2002a,b; Disney, Towill 2006; Kannan et al. 2013). This study makes an attempt to investigate IT-related issues within Indian industries (R4, R5).

\subsection{Benefits and effects of VMI}

Småros et al. (2003) showed how manufacturing companies could benefit even from a partial increase in demand visibility. Wilson (2007) investigated the effect of a transportation disruption on supply chain performance using system dynamics simulation, and in a similar study Sari (2008) used discrete event simulation to explore the performance increase achieved by VMI under different supply chain scenarios with a focus on capacity issues.

Disputes over the benefits of VMI arise because few quantitative analyses are available, and in those that do exist, general attributes of the agreements are understood only in 
some instances. That research gap makes it difficult to assess and to justify conceptual models of VMI contracts. For a few authors, uncertainty issues were important. For example, Song and Dinwoodie (2008) addressed the inventory management problem in a supply chain with uncertain replenishment lead-times and uncertain customer demands. An integrated inventory management policy was developed with two pull-type VMI policies and compared to a traditional retailer managed inventory policy.

Although an exhaustive literature review is beyond the scope of this paper and study, we have attempted to find effects and barriers associated with implementation of VMI in an Indian context (R2, R6).

\section{Methodology}

We conducted a survey among Indian industries that focused on some issues related to VMI practices. A few differences were discussed in Borade and Bansod (2012). This paper presents the other vital differences.

The objectives of research are:

1. To explore the dissimilarities among sectors of SMEs adopting VMI.

2. To delve into the ongoing VMI practices in Indian SMEs.

3. To expand and develop the knowledge base related to VMI practices in an Indian context.

Organizations having an annual turnover of less than 10 million dollars were considered as small and medium companies; questionnaires were sent to such SMEs. In order to ensure validity of content, the questionnaire was tested on 15 academics and managers who were familiar with the concept. The construct validity was verified by factor analysis. Kim and Mueller (1978) suggested that items which have a Cronbach's Alpha of more than 0.40 represent the construct validity. Therefore, items having values greater than 0.45 were retained. As the literature suggests that VMI is most frequently adopted in manufacturing and service sectors, these SMEs were carefully selected from the Directory of ISO 9000 certified companies. In addition to the above industries, we also included the industries personally known to us. The survey was carried out from January 2011 to July 2011. Questionnaires were sent through post; however, follow-up was done by email and telephone whenever possible. A total of 400 SMEs located in the central and northern states of India were the target industries to which the questionnaires were sent. Because most of the manufacturing industries are concentrated in the northern and central states of India, the survey sample could conveniently represent all Indian SMEs. After periodic reminders and continuous emails, out of the 400 questionnaires sent, only 136 were returned. Of these 136, 12 were incomplete and unusable; therefore, they were deleted from further analysis. Thus, 124 out of 400, i.e. a response rate of $31 \%$, was achieved which can be considered as a very good response rate in an Indian environment. The general profile of respondents is presented in Table 1 . Table 1 clearly shows that almost $67 \%$ of industries were from the manufacturing sector and $33 \%$ of SMEs were from the service sector. It can also be seen from Table 1 that $50 \%$ of organizations are small enterprises, whereas 50\% are medium-sized enterprises (Borade, Bansod 2012). 
Table 1. Profile of respondents

\begin{tabular}{|c|c|c|c|c|c|c|c|c|c|c|c|}
\hline \multirow[b]{2}{*}{$\begin{array}{l}\text { Descrip- } \\
\text { tion }\end{array}$} & \multicolumn{2}{|c|}{$\begin{array}{l}\text { Sector of } \\
\text { SME }\end{array}$} & \multicolumn{3}{|c|}{$\begin{array}{l}\text { Number of } \\
\text { employees }\end{array}$} & \multicolumn{3}{|c|}{ Experience in years } & \multicolumn{3}{|c|}{ Job title } \\
\hline & 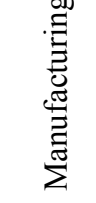 & $\sum_{\substack{0 \\
心}}^{0}$ & $\begin{array}{l}8 \\
n \\
0 \\
\vdots \\
5\end{array}$ & $\begin{array}{l}8 \\
8 \\
\stackrel{8}{8} \\
8 \\
i\end{array}$ & $\begin{array}{l}8 \\
8 \\
0 \\
8 \\
8 \\
0\end{array}$ & $\begin{array}{l}n \\
0 \\
0\end{array}$ & $\begin{array}{l}0 \\
\stackrel{0}{0} \\
0\end{array}$ & $\begin{array}{l}0 \\
0 \\
0 \\
8 \\
8\end{array}$ & 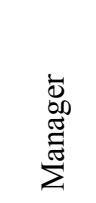 & 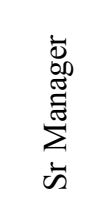 & $\sum_{\substack{\sum_{0} \\
\sum}}$ \\
\hline $\begin{array}{l}\text { Percent- } \\
\text { age of } \\
\text { respond- } \\
\text { ents }\end{array}$ & 67.75 & 32.25 & 28.42 & 22.58 & 48.00 & 48.30 & 30.64 & 21.06 & 32.27 & 51.60 & 16.13 \\
\hline
\end{tabular}

A test of reliability on the measurement instrument was carried out to determine its ability to yield consistent measurements. In this study, the principal component method of factor analysis (PCMFA) was used for factor loading. Factor analysis was conducted on items under each measure based upon principal component analysis using XLSTAT2008. An assumption was made that sectors of SME differ with respect to VMI practices. In this research, the variances of two samples were to be compared. Therefore, to test the equality of two populations, an F-test was conducted.

\section{Observations and discussions}

\subsection{Management tools assisting VMI}

VMI is a business performance improvement strategy, but, used alone, it cannot improve business performance. It has to be supported by other management tools. To determine which management tools assist with the adoption of VMI, respondents were asked to rank assistors on a five-point scale ranging from "somewhat important" to "very important". One of the major goals of VMI is inventory reduction, which is the sole goal of the Just In Time (JIT) strategy. This ideology is reflected in results indicated in Table 2. It was observed that SMEs found JIT practices very important (overall rating 4.161) for adopting VMI, and "Total Productive Maintenance" was considered a tool of somewhat importance (overall rating 3.352). The importance ratings were the same for both the manufacturing and service sectors. Regarding statistical differences in sectors, the "Total Productive Maintenance" variable indicated a significant difference at 0.05 levels, while other variables exhibited no significant differences. JIT demands the production process to be managed in such a way that no inventory or just in time inventory is required. There should not be any defects in the intermediate and final stages of the production process. TQM philosophy works on the same principle, too. This infers that VMI is closely aligned with both JIT and TQM; therefore, the importance to these issues is well understood in the context of VMI implementation. 
Table 2. Management tool assisting VMI

\begin{tabular}{|c|c|c|c|c|c|c|c|c|c|c|}
\hline & & & & & & & & Alp & $\begin{array}{r}\mathrm{P}=\mathrm{C} \\
\text { Cronb } \\
\text { ha }=0 .\end{array}$ & $\begin{array}{l}.05 \\
\text { ch's } \\
60681587\end{array}$ \\
\hline Variable & $\sum_{\text {हี }}^{\overparen{E}}$ & 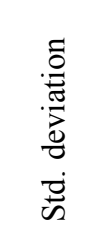 & 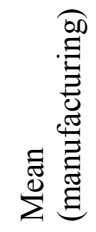 & 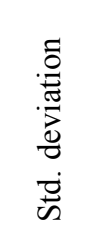 & 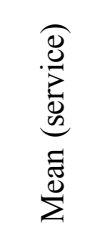 & 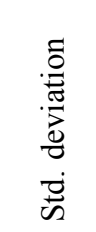 & 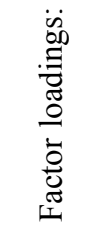 & 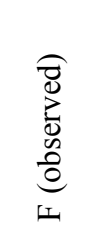 & 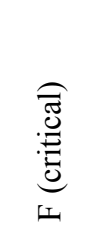 & 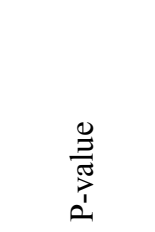 \\
\hline $\begin{array}{l}\text { Total quality } \\
\text { management }\end{array}$ & 3.710 & 0.998 & 3.524 & 1.018 & 4.053 & 0.848 & 0.621 & 1.440 & 2.380 & $\begin{array}{c}0.407 \\
\text { Accept H0 }\end{array}$ \\
\hline Just In Time & 4.161 & 0.927 & 3.905 & 0.932 & 4.684 & 0.671 & 0.573 & 1.929 & 2.380 & $\begin{array}{c}0.134 \\
\text { Accept H0 }\end{array}$ \\
\hline $\begin{array}{l}\text { Business } \\
\text { process } \\
\text { reengineering }\end{array}$ & 3.519 & 1.110 & 3.048 & 1.058 & 4.158 & 0.765 & 0.752 & 1.915 & 2.380 & $\begin{array}{c}0.138 \\
\text { Accept H0 }\end{array}$ \\
\hline $\begin{array}{l}\text { Enterprise } \\
\text { resource } \\
\text { planning }\end{array}$ & 3.613 & 0.981 & 3.476 & 1.065 & 3.895 & 0.737 & 0.772 & 2.084 & 2.380 & $\begin{array}{c}0.095 \\
\text { Accept H0 }\end{array}$ \\
\hline $\begin{array}{l}\text { Total } \\
\text { productive } \\
\text { maintenance }\end{array}$ & 3.452 & 1.141 & 3.286 & 1.293 & 3.789 & 0.631 & 0.780 & 4.206 & 2.380 & $\begin{array}{c}0.002 \\
\text { Accept Ha }\end{array}$ \\
\hline
\end{tabular}

\subsection{Communication mode}

VMI needs continuous interaction between internal and external supply chain members. Respondents were asked to indicate the most frequently adopted mode of communication. A five-point scale from "rarely" to "mostly" was used to measure the responses. Results (Table 3) indicated that despite the latest available modes of communication and information sharing, traditional modes of communication were used. It was found that the most commonly used mode of communication was "Email" (overall rating 4.41). Surprisingly, "EDI" (overall rating 2.774) was a rarely used mode of communication.

The results for the manufacturing sector and the service sector were in line with the results of the overall sample. Moreover, all the three samples followed a consistent ranking pattern. Using traditional modes of communication restricts and controls information sharing; hence, there is a need for Indian SMEs to use latest communication modes.

\subsection{Information technology assisting VMI}

The basic premise of VMI is real time information sharing and the information technology enablement of the supply chain makes it very easy. To find the differences among sectors of SMEs regarding IT tools, respondents were asked to indicate the extent to which the IT tools were used on a five-point scale from "to a small extent" to "to a great extent" (Table 4). 
Table 3. Communication mode

\begin{tabular}{|c|c|c|c|c|c|c|c|c|c|c|}
\hline & & & & & & & & \multicolumn{3}{|c|}{$\begin{array}{c}\mathrm{P}=0.05 \\
\text { Cronbach's } \\
\text { Alpha }=0.686440053\end{array}$} \\
\hline Variable & $\sum_{\text {है }}^{\stackrel{\Xi}{\Sigma}}$ & 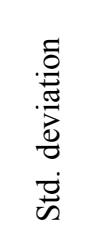 & 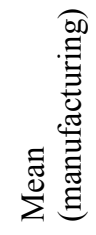 & 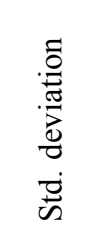 & 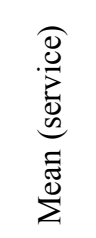 & 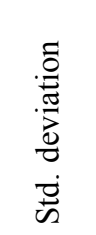 & 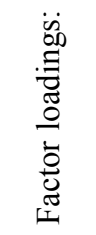 & $\begin{array}{l}\overparen{8} \\
0 \\
0 \\
0 \\
0 \\
0\end{array}$ & : & 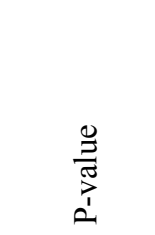 \\
\hline Email & 4.419 & 0.950 & 4.143 & 1.049 & 5.000 & 0.000 & 0.845 & 1.829 & 2.380 & $\begin{array}{c}0.168 \\
\text { Accept H0 }\end{array}$ \\
\hline Fax & 3.452 & 1.327 & 3.381 & 1.188 & 3.526 & 1.611 & 0.759 & 0.544 & 2.380 & $\begin{array}{c}0.107 \\
\text { Accept H0 }\end{array}$ \\
\hline Intranet & 4.116 & 1.083 & 3.476 & 1.018 & 3.579 & 1.261 & 0.499 & 0.651 & 2.380 & $\begin{array}{c}0.254 \\
\text { Accept H0 }\end{array}$ \\
\hline Telephone & 4.258 & 1.085 & 4.000 & 1.210 & 4.889 & 0.323 & 0.753 & 13.994 & 2.380 & $\begin{array}{c}0.0001 \\
\text { Accept Ha }\end{array}$ \\
\hline EDI & 2.774 & 1.220 & 2.762 & 1.358 & 2.789 & 0.918 & 0.742 & 2.190 & 2.380 & $\begin{array}{c}0.075 \\
\text { Accept H0 }\end{array}$ \\
\hline
\end{tabular}

Table 4. Information technology assisting VMI

\begin{tabular}{|c|c|c|c|c|c|c|c|c|c|c|}
\hline & & & & & & & & \multicolumn{3}{|c|}{$\begin{array}{c}\mathrm{P}=0.05 \\
\text { Cronbach's } \\
\text { Alpha }=0.606859249\end{array}$} \\
\hline Variable & 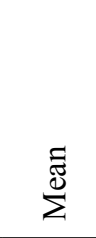 & 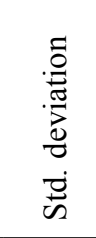 & 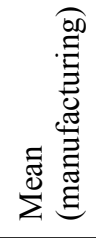 & 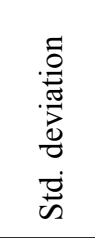 & 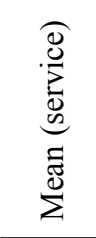 & 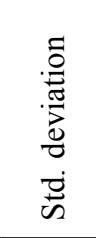 & 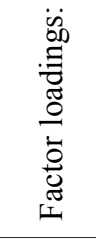 & $\begin{array}{l}\stackrel{0}{0} \\
\underbrace{0}_{1} \\
0 \\
0 \\
0 \\
0 \\
0\end{array}$ & 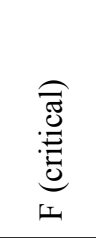 & 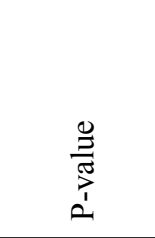 \\
\hline RFID & 2.419 & 1.167 & 2.381 & 1.229 & 2.474 & 0.573 & 0.848 & 1.311 & 2.380 & $\begin{array}{c}0.545 \\
\text { Accept H0 }\end{array}$ \\
\hline Extranet & 2.645 & 1.042 & 2.714 & 1.175 & 2.789 & 0.918 & 0.603 & 1.639 & 2.380 & $\begin{array}{c}0.259 \\
\text { Accept H0 }\end{array}$ \\
\hline Internet & 3.942 & 1.085 & 4.381 & 0.909 & 4.684 & 0.671 & 0.674 & 1.836 & 2.380 & $\begin{array}{c}0.165 \\
\text { Accept H0 }\end{array}$ \\
\hline SAP/BAAN & 4.697 & 1.289 & 3.905 & 1.428 & 4.474 & 0.841 & 0.559 & 2.882 & 2.380 & $\begin{array}{c}0.018 \\
\text { Accept Ha }\end{array}$ \\
\hline
\end{tabular}

This research observed that SMEs have recognized the importance of using SAP/BAAN technologies. Respondents believed that "SAP/BAAN" assists VMI to a great extent (overall rating 4.097). SMEs considered "Internet" as a vital tool to a fairer extent (overall rating 3.94). This must be a result of new web based B-2-B systems. 
Regarding statistical differences in sectors, the "SAP/BAAN" variable indicated a significant difference at 0.05 levels, while for other variables there were no significant differences.

\subsection{Activities carried out using supply chain software.}

In order to cope with inefficiencies in demand management and order fulfillment processes, organizations use supply chain software. The survey sought further information on the activities that are handled most frequently, ranking them on a five-point scale from "rarely" to "mostly" (Table 5).

It was found that "Generation of purchase order" (overall rating 4.22) was mostly handled by software. However, SMEs were reluctant in making payments electronically. "Electronic Payments" was rarely done (overall rating 3.258) using supply chain software. It can be concluded that SMEs still adopt conventional methods for making payments. Regarding statistical differences in sectors, the "Generation of purchase order" variable indicated a significant difference at 0.05 levels, while for other variables there were no significant differences.

Table 5. Activities carried out in VMI module using supply chain software

\begin{tabular}{|c|c|c|c|c|c|c|c|c|c|c|}
\hline & & & & & & & & Alph & $\begin{array}{r}\mathrm{P}=0 \\
\text { Cronba } \\
\mathrm{a}=0.8\end{array}$ & $\begin{array}{l}05 \\
\text { ch's } \\
17870522\end{array}$ \\
\hline Variable & 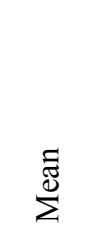 & 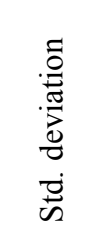 & 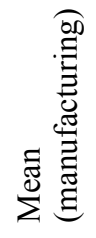 & 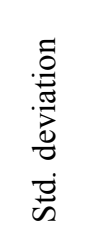 & 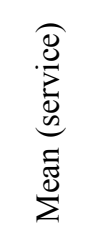 & 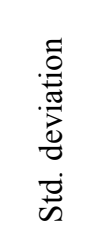 & 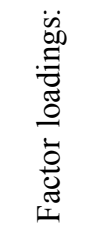 & $\begin{array}{l}\hat{\mathbb{D}} \\
\stackrel{0}{0} \\
\underbrace{0}_{\square} \\
0 \\
0\end{array}$ & 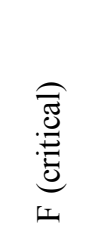 & 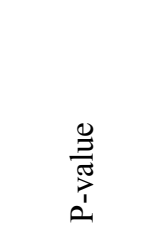 \\
\hline $\begin{array}{l}\text { Automatic } \\
\text { forecasting } \\
\text { of good }\end{array}$ & 3.806 & 0.884 & 3.714 & 0.944 & 4.500 & 0.745 & 0.976 & 1.606 & 2.380 & $\begin{array}{c}0.279 \\
\text { Accept H0 }\end{array}$ \\
\hline $\begin{array}{l}\text { Advanced } \\
\text { shipment } \\
\text { notices } \\
\end{array}$ & 3.935 & 0.956 & 3.619 & 0.882 & 4.079 & 0.769 & 0.870 & 1.317 & 2.380 & $\begin{array}{c}0.536 \\
\text { Accept H0 }\end{array}$ \\
\hline $\begin{array}{l}\text { Generation } \\
\text { of purchase } \\
\text { order }\end{array}$ & 4.226 & 1.137 & 4.357 & 0.850 & 3.895 & 1.595 & 0.890 & 0.284 & 2.380 & $\begin{array}{c}0.001 \\
\text { Accept } \mathrm{Ha}\end{array}$ \\
\hline $\begin{array}{l}\text { Electronic } \\
\text { payments }\end{array}$ & 3.258 & 1.342 & 3.452 & 1.383 & 2.842 & 1.214 & 0.857 & 1.298 & 2.380 & $\begin{array}{c}0.561 \\
\text { Accept H0 }\end{array}$ \\
\hline
\end{tabular}

\subsection{Barriers while implementing VMI}

VMI demands change on all fronts and therefore organizations need to overcome the barriers. Respondents were asked to rate the barriers on a five-point scale from "to a small extent" to "to a great extent".

Table 6 shows the responses. SMEs found "Organizational Barriers" (overall rating 3.484 ) to be the most highly ranked and greatest barrier. Adoption of VMI requires huge 
capital investment and it is believed that financial constraints may hamper the adoption process. But the results indicated that for SMEs, the "Financial Barriers" (overall rating 3.161) are barriers "to a small extent" only. While adopting VMI in the manufacturing sector, the changes are due to the technological factors; therefore the highest concern to technological barriers is well understood. In the case of the service sector, the changes happened to be strategic and may entail some financial obligations. This ideology is reflected in the survey results.

Only "Operational Barriers" exhibited significant statistical differences; other barriers exhibited no statistical differences.

Table 6. Barriers while implementing VMI

\begin{tabular}{|c|c|c|c|c|c|c|c|c|c|c|}
\hline \multirow[b]{2}{*}{ Variable } & \multirow[b]{2}{*}{$\sum_{\Sigma}^{\Xi}$} & \multirow[b]{2}{*}{ 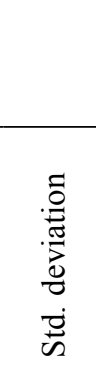 } & \multirow[b]{2}{*}{ 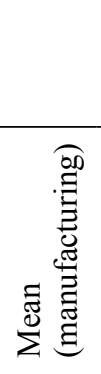 } & \multirow[b]{2}{*}{ 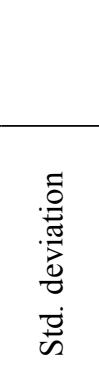 } & \multirow[b]{2}{*}{ 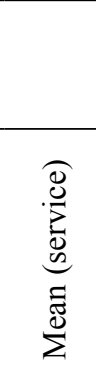 } & \multirow[b]{2}{*}{ 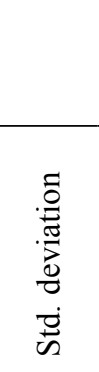 } & \multirow[b]{2}{*}{ 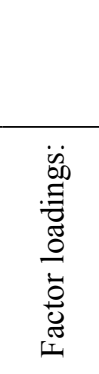 } & \multicolumn{3}{|c|}{$\begin{array}{c}\mathrm{P}=0.05 \\
\text { Cronbach's } \\
\text { Alpha }=0.621228376\end{array}$} \\
\hline & & & & & & & & $\begin{array}{l}\hat{D} \\
\stackrel{0}{0} \\
\underbrace{0}_{1} \\
0 \\
0 \\
0\end{array}$ & 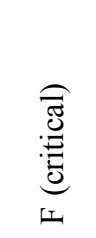 & 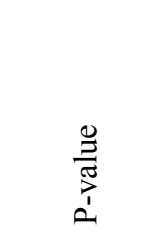 \\
\hline Technological & 3.419 & 1.167 & 3.190 & 1.234 & 3.947 & 0.848 & 0.481 & 2.118 & 2.380 & $\begin{array}{c}0.088 \\
\text { Accept H0 }\end{array}$ \\
\hline Cultural & 3.355 & 0.870 & 3.190 & 0.917 & 3.684 & 0.671 & 0.517 & 1.867 & 2.380 & $\begin{array}{c}0.154 \\
\text { Accept H0 }\end{array}$ \\
\hline Financial & 3.161 & 1.428 & 3.048 & 1.481 & 3.421 & 1.346 & 0.781 & 1.210 & 2.380 & $\begin{array}{c}0.679 \\
\text { Accept H0 }\end{array}$ \\
\hline Organizational & 3.484 & 1.446 & 3.048 & 1.413 & 4.368 & 1.065 & 0.789 & 1.761 & 2.380 & $\begin{array}{c}0.196 \\
\text { Accept H0 }\end{array}$ \\
\hline Operational & 3.226 & 1.298 & 2.905 & 1.358 & 3.947 & 0.848 & 0.858 & 2.564 & 2.380 & $\begin{array}{c}0.034 \\
\text { Accept Ha }\end{array}$ \\
\hline
\end{tabular}

\subsection{Major organizational obstacles experienced while implementing VMI}

In this section specific organizational factors that affect the VMI adoption process are discussed. If these issues are studied properly, then the adoption process becomes very smooth. Respondents were asked to indicate the level of the obstacles on the Likert scale, from "somewhat significant" to "very significant". The responses are summarized in Table 7.

There was a general agreement that "Problem in understanding the concept" (overall rating 3.516) was a very significant obstacle. Literature has reported that for SMEs, "Fear of information system breakdown" is one of the biggest hurdles in implementing VMI. However, the results obtained in this work contradict that belief. According to respondents, "Fear of information system breakdown" (overall rating 2.484) was a somewhat significant obstacle only. 
Table 7. Major organizational obstacles

\begin{tabular}{|c|c|c|c|c|c|c|c|c|c|c|}
\hline \multirow{2}{*}{ Variable } & \multirow[b]{2}{*}{$\sum^{\text {हี }}$} & \multirow[b]{2}{*}{ 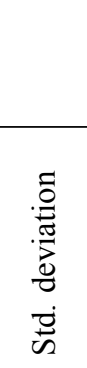 } & \multirow[b]{2}{*}{ 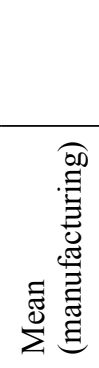 } & \multirow[b]{2}{*}{ 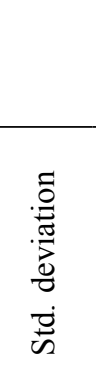 } & \multirow[b]{2}{*}{ 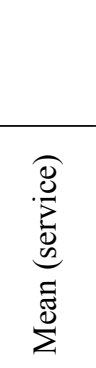 } & \multirow[b]{2}{*}{ 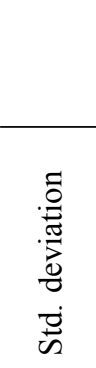 } & \multirow[b]{2}{*}{ 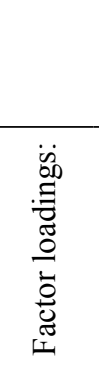 } & \multicolumn{3}{|c|}{$\begin{array}{c}\mathrm{P}=0.05 \\
\text { Cronbach's } \\
\text { Alpha }=0.642444932\end{array}$} \\
\hline & & & & & & & & 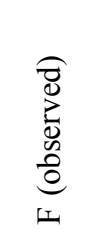 & 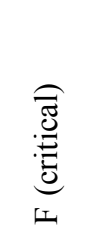 & $\begin{array}{l}\stackrel{0}{7} \\
\frac{\pi}{2} \\
\overbrace{1}^{1}\end{array}$ \\
\hline $\begin{array}{l}\text { Improper } \\
\text { identification } \\
\text { of business } \\
\text { needs }\end{array}$ & 3.323 & 1.212 & 3.095 & 1.165 & 3.789 & 1.228 & 0.736 & 2.564 & 2.380 & $\begin{array}{c}0.034 \\
\text { Accept Ha }\end{array}$ \\
\hline $\begin{array}{l}\text { Problem in } \\
\text { understanding } \\
\text { the concept }\end{array}$ & 3.516 & 1.083 & 3.571 & 1.063 & 3.368 & 1.165 & 0.596 & 0.899 & 2.380 & $\begin{array}{c}0.751 \\
\text { Accept H0 }\end{array}$ \\
\hline $\begin{array}{l}\text { Resistance } \\
\text { to change }\end{array}$ & 3.258 & 1.055 & 3.143 & 1.049 & 3.526 & 1.073 & 0.495 & 1.213 & 2.380 & $\begin{array}{c}0.674 \\
\text { Accept H0 }\end{array}$ \\
\hline $\begin{array}{l}\text { Lack of } \\
\text { awareness }\end{array}$ & 2.806 & 1.038 & 2.762 & 1.031 & 2.947 & 1.079 & 0.679 & 0.956 & 2.380 & $\begin{array}{c}0.869 \\
\text { Accept H0 }\end{array}$ \\
\hline $\begin{array}{l}\text { Fear of } \\
\text { information } \\
\text { system } \\
\text { breakdown }\end{array}$ & 2.484 & 1.020 & 2.524 & 1.065 & 2.421 & 0.961 & 0.635 & 0.914 & 2.380 & $\begin{array}{c}0.783 \\
\text { Accept H0 }\end{array}$ \\
\hline $\begin{array}{l}\text { Low level of } \\
\text { supply chain } \\
\text { integration }\end{array}$ & 2.935 & 1.172 & 2.905 & 1.206 & 3.000 & 1.155 & 0.458 & 1.227 & 2.380 & $\begin{array}{c}0.655 \\
\text { Accept H0 }\end{array}$ \\
\hline
\end{tabular}

It can be concluded that SMEs have left the traditional ways of business and are ready to change. Regarding statistical differences in sectors, the "Improper identification of business needs" variable indicated a significant difference at 0.05 levels, while for other variables there were no significant differences.

\subsection{Problems related to information sharing}

Real-time and accurate information sharing is an essential requirement of VMI. But due to strategic and cultural organizational factors, information sharing is affected. Respondents were asked to rate the problems encountered during the information sharing (I.S.), in the context of VMI on a five-point scale from "minor" to "major".

From the results (Table 8) it is found that "Unwillingness to share the information" (overall rating 3.823) was the major problem while adopting VMI. According to respondents, "Discouragement for information sharing" (overall rating 3.129) was a minor problem. It indicates that management was ready for the change but the strategies were not clear to the employees. For any business enterprise the most important issue is the information pertinent to their business. What would be the consequences if this infor- 
mation goes to competitors? As a result, SMEs considered "Unwillingness to share the information" as the major problem in adopting VMI. No doubt information sharing is a double-edged sword, and if it is not used properly it can cause more harm than good.

There was a disparity related to the problem of "Information sharing platform" among the sectors of SMEs, while for other variables there were no significant differences.

Table 8. Problems related to information sharing

\begin{tabular}{|c|c|c|c|c|c|c|c|c|c|c|}
\hline \multirow[b]{2}{*}{ Variable } & \multirow[b]{2}{*}{$\sum^{\Xi}$} & \multirow[b]{2}{*}{ 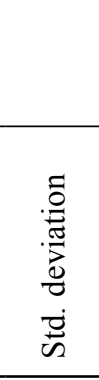 } & \multirow[b]{2}{*}{ 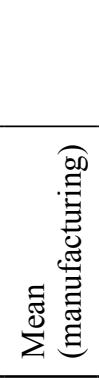 } & \multirow[b]{2}{*}{ 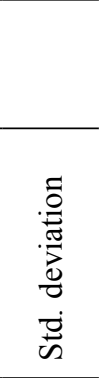 } & \multirow[b]{2}{*}{ 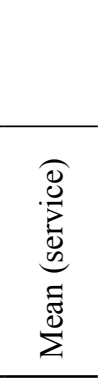 } & \multirow[b]{2}{*}{ 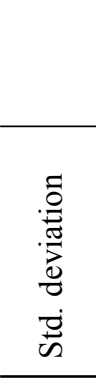 } & \multirow[b]{2}{*}{ 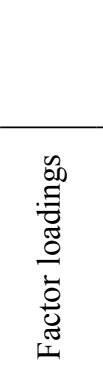 } & \multicolumn{3}{|c|}{$\begin{array}{c}\mathrm{P}=0.05 \\
\text { Cronbach's } \\
\text { Alpha }=0.718739227\end{array}$} \\
\hline & & & & & & & & $\begin{array}{l}\text { O্d } \\
\underbrace{0}_{0} \\
0 \\
0 \\
0 \\
0 \\
0\end{array}$ & 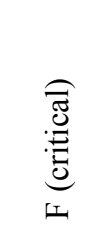 & 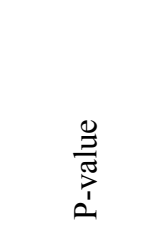 \\
\hline $\begin{array}{l}\text { Unwillingness } \\
\text { to share } \\
\text { information }\end{array}$ & 3.823 & 1.109 & 3.786 & 0.925 & 3.842 & 1.463 & 0.618 & 0.400 & 2.380 & $\begin{array}{c}0.119 \\
\text { Accept H0 }\end{array}$ \\
\hline $\begin{array}{l}\text { Missing sharing } \\
\text { platform }\end{array}$ & 3.145 & 1.084 & 3.024 & 1.179 & 3.421 & 0.838 & 0.824 & 1.980 & 2.380 & $\begin{array}{c}0.015 \\
\text { Accept Ha }\end{array}$ \\
\hline $\begin{array}{l}\text { Poor } \\
\text { information } \\
\text { sharing } \\
\text { strategies }\end{array}$ & 3.355 & 1.073 & 3.310 & 1.158 & 3.216 & 0.902 & 0.659 & 1.650 & 2.380 & $\begin{array}{c}0.252 \\
\text { Accept H0 }\end{array}$ \\
\hline $\begin{array}{l}\text { Discouragement } \\
\text { of information } \\
\text { sharing }\end{array}$ & 3.129 & 0.799 & 3.000 & 0.855 & 3.171 & 0.607 & 0.484 & 1.986 & 2.380 & $\begin{array}{c}0.118 \\
\text { Accept H0 }\end{array}$ \\
\hline
\end{tabular}

\subsection{Operational benefits of VMI}

As a result of VMI adoption, day-to-day business activities are affected.

According to respondents, "Improved responsiveness" (overall rating 4.258) was the significant benefit. "Improved Customer Loyalty" (overall rating 3.581) was shown to be a somewhat significant benefit (Table 9).

Results indicated that VMI improved the responsiveness and efficiency of the supply chain. Research also observed a small improvement in customer loyalty. Managers must look at these issues and should be assured of customer loyalty.

It appeared from the results that the service sector was not able to capitalize on the concept and could not improve the profit and the customer base. There was not a general agreement with respect to "Reduced stock outs" among the sectors of SMEs. The variable showed a significant difference at the 0.05 level, while for other variables there were no significant differences. 
Table 9. Operational benefits of VMI

\begin{tabular}{|c|c|c|c|c|c|c|c|c|c|c|}
\hline \multirow{2}{*}{ Variable } & \multirow[b]{2}{*}{$\sum^{\nexists \Xi}$} & \multirow[b]{2}{*}{ 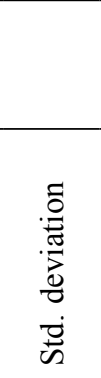 } & \multirow[b]{2}{*}{ 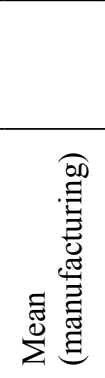 } & \multirow[b]{2}{*}{ 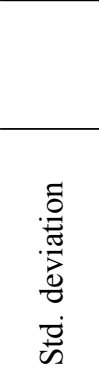 } & \multirow[b]{2}{*}{ 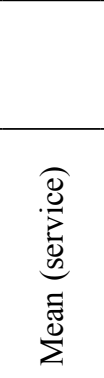 } & \multirow[b]{2}{*}{ 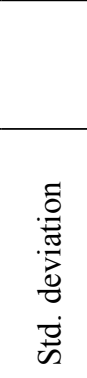 } & \multirow[b]{2}{*}{ 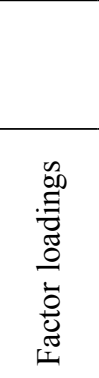 } & \multicolumn{3}{|c|}{$\begin{array}{c}\mathrm{P}=0.05 \\
\text { Cronbach's } \\
\text { Alpha }=0.777057433\end{array}$} \\
\hline & & & & & & & & 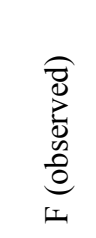 & 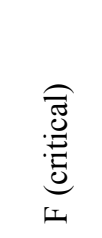 & $\begin{array}{l}\frac{0}{\pi} \\
\substack{\pi \\
1} \\
2\end{array}$ \\
\hline $\begin{array}{l}\text { Improved } \\
\text { efficiency }\end{array}$ & 4.065 & 0.807 & 4.190 & 0.862 & 3.789 & 0.631 & 0.747 & 1.869 & 2.380 & $\begin{array}{c}0.153 \\
\text { Accept H0 }\end{array}$ \\
\hline $\begin{array}{l}\text { Improved } \\
\text { decision making }\end{array}$ & 3.677 & 1.290 & 3.429 & 1.346 & 4.158 & 1.015 & 0.862 & 1.760 & 2.380 & $\begin{array}{c}0.196 \\
\text { Accept H0 }\end{array}$ \\
\hline $\begin{array}{l}\text { Reduction in } \\
\text { transition cost }\end{array}$ & 3.903 & 1.264 & 3.810 & 1.273 & 4.053 & 1.268 & 0.858 & 1.008 & 2.380 & $\begin{array}{c}0.974 \\
\text { Accept H0 }\end{array}$ \\
\hline $\begin{array}{l}\text { Improved } \\
\text { responsiveness }\end{array}$ & 4.258 & 0.922 & 4.048 & 0.962 & 4.684 & 0.671 & 0.725 & 2.053 & 2.380 & $\begin{array}{c}0.101 \\
\text { Accept H0 }\end{array}$ \\
\hline $\begin{array}{l}\text { Improved } \\
\text { replenishment } \\
\text { process }\end{array}$ & 3.839 & 1.027 & 3.619 & 1.103 & 4.316 & 0.671 & 0.674 & 2.703 & 2.380 & $\begin{array}{c}0.026 \\
\text { Accept Ha }\end{array}$ \\
\hline $\begin{array}{l}\text { Inventory } \\
\text { reductions }\end{array}$ & 3.806 & 1.099 & 3.714 & 1.175 & 4.000 & 0.943 & 0.901 & 1.552 & 2.380 & $\begin{array}{c}0.315 \\
\text { Accept H0 }\end{array}$ \\
\hline $\begin{array}{l}\text { Reduced stock } \\
\text { outs }\end{array}$ & 3.871 & 1.079 & 3.667 & 1.183 & 4.316 & 0.671 & 0.778 & 3.105 & 2.380 & $\begin{array}{c}0.012 \\
\text { Accept Ha }\end{array}$ \\
\hline $\begin{array}{l}\text { Reduced supply } \\
\text { chain cost }\end{array}$ & 3.871 & 1.166 & 3.905 & 1.206 & 3.789 & 1.134 & 0.749 & 1.130 & 2.380 & $\begin{array}{c}0.804 \\
\text { Accept H0 }\end{array}$ \\
\hline Improved profit & 3.645 & 1.161 & 3.857 & 1.181 & 3.211 & 1.032 & 0.779 & 1.309 & 2.380 & $\begin{array}{c}0.546 \\
\text { Accept H0 }\end{array}$ \\
\hline $\begin{array}{l}\text { Improved } \\
\text { customer } \\
\text { Loyalty }\end{array}$ & 3.581 & 1.080 & 3.524 & 1.194 & 3.737 & 0.806 & 0.653 & 2.197 & 2.380 & $\begin{array}{c}0.074 \\
\text { Accept H0 }\end{array}$ \\
\hline
\end{tabular}

\subsection{Strategic benefits of VMI}

This section investigated the benefits which give a strategic competency. Results (Table 10) also show that "Improved channel relations" (overall rating 3.710) was a very significant benefit, and "Improved Strategic Competitiveness" (overall rating 3.258) was a somewhat significant benefit. VMI is a cooperative process involving many channel partners and therefore the rating of improved channel relations and better resource utilization seems to be justified.

The results of both the sectors were in line with the overall sample. There were no significant statistical differences with respect to strategic benefits. 
Table 10. Strategic benefit of VMI

\begin{tabular}{|c|c|c|c|c|c|c|c|c|c|c|}
\hline & & & & & & & & Alph & $\begin{array}{r}\mathrm{P}=0 \\
\text { Cronb } \\
\mathrm{a}=0.6\end{array}$ & $\begin{array}{l}.05 \\
\text { ch's } \\
06709265\end{array}$ \\
\hline Variable & $\sum_{\mathbb{E}}^{\mathbb{E}}$ & 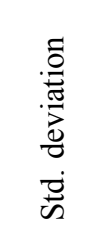 & 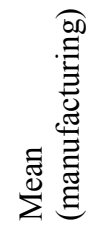 & 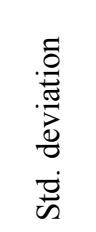 & 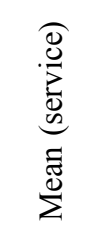 & 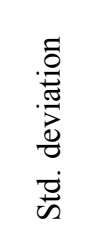 & 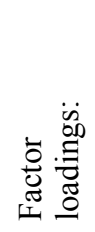 & $\begin{array}{l}\overparen{8} \\
8 \\
0 \\
0 \\
0 \\
0 \\
0\end{array}$ & 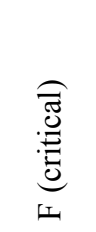 & 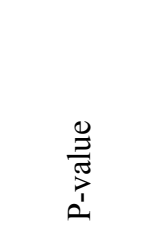 \\
\hline $\begin{array}{l}\text { Improved } \\
\text { channel } \\
\text { relations }\end{array}$ & 3.710 & 1.030 & 3.619 & 1.147 & 4.000 & 0.737 & 0.679 & 2.417 & 2.380 & $\begin{array}{c}0.046 \\
\text { Accept Ha }\end{array}$ \\
\hline $\begin{array}{l}\text { Better resource } \\
\text { utilization }\end{array}$ & 3.645 & 0.870 & 3.476 & 0.917 & 3.895 & 0.667 & 0.682 & 1.892 & 2.380 & $\begin{array}{c}0.145 \\
\text { Accept H0 }\end{array}$ \\
\hline $\begin{array}{l}\text { Improved } \\
\text { strategic } \\
\text { competitiveness }\end{array}$ & 3.258 & 1.085 & 3.286 & 1.043 & 3.211 & 1.228 & 0.496 & 0.721 & 2.380 & $\begin{array}{c}0.379 \\
\text { Accept H0 }\end{array}$ \\
\hline
\end{tabular}

\subsection{The effect of VMI on quality parameters}

The effects on quality parameters were investigated. Respondents were asked what the effects of VMI on quality parameters were.

VMI resulted in better service to customers (Table 11). For SMEs "Improved Customer service" (overall rating 4.097) was a very significant effect of VMI adoption. However, the effect of VMI on "Quality of product" was ranked somewhat significant (overall rating 3.194). It can be concluded that VMI does not help in improving the product quality. Management must infuse quality technologies along with VMI drivers for improving business performance.

The responses of both sectors were in line with the overall sample.

Table 11. Effect on quality parameters

\begin{tabular}{|c|c|c|c|c|c|c|c|c|c|c|}
\hline \multirow[b]{2}{*}{ Variable } & \multirow[b]{2}{*}{ 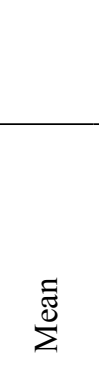 } & \multirow[b]{2}{*}{ 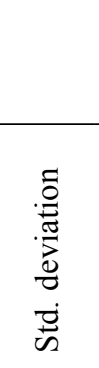 } & \multirow[b]{2}{*}{ 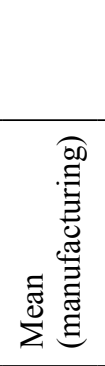 } & \multirow[b]{2}{*}{ 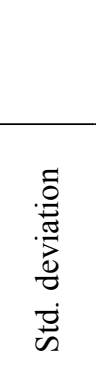 } & \multirow[b]{2}{*}{ 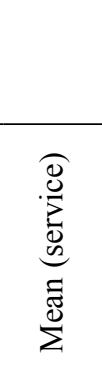 } & \multirow[b]{2}{*}{ 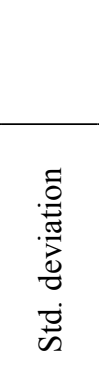 } & \multirow[b]{2}{*}{ 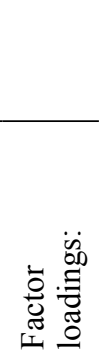 } & \multicolumn{3}{|c|}{$\begin{array}{c}\mathrm{P}=0.05 \\
\text { Cronbach's } \\
\text { Alpha }=0.618395197\end{array}$} \\
\hline & & & & & & & & 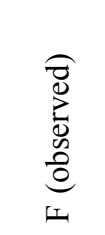 & 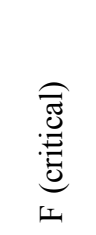 & 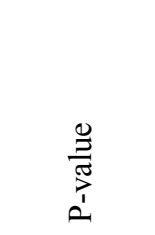 \\
\hline $\begin{array}{l}\text { Improved } \\
\text { customer service }\end{array}$ & 4.097 & 0.900 & 3.857 & 0.899 & 4.579 & 0.692 & 0.567 & 1.686 & 2.380 & $\begin{array}{c}0.232 \\
\text { Accept } \mathrm{H} 0\end{array}$ \\
\hline $\begin{array}{l}\text { Reduced product } \\
\text { returns }\end{array}$ & 3.548 & 0.881 & 3.667 & 1.004 & 3.316 & 0.478 & 0.857 & 4.420 & 2.380 & $\begin{array}{c}0.001 \\
\text { Accept Ha }\end{array}$ \\
\hline $\begin{array}{l}\text { Better quality } \\
\text { of products }\end{array}$ & 3.194 & 1.099 & 3.238 & 1.165 & 3.053 & 0.970 & 0.618 & 1.441 & 2.380 & $\begin{array}{c}0.407 \\
\text { Accept H0 }\end{array}$ \\
\hline
\end{tabular}




\subsection{The effect of VMI on cost parameters}

Wal-mart initiated VMI to reduce their inventory and inventory costs. However, other elements of total cost are affected on account of VMI. This section reveals investigations related to the effects of VMI on cost parameters. The results are shown in Table 12.

VMI is all about inventory optimization. The major concern is inventory and its associated cost. Therefore, there was no surprise that a very significant effect was found on "Inventory carrying cost" (overall rating 4.161). The effect on "Logistics Cost" was somewhat significant. It may be due to improper logistics management strategies. If organizations could not handle it, outsourcing the job to a third party could be a possible solution. There was no general agreement with respect to "Reduction in logistics cost" among the sectors of SMEs. The variable showed a significant difference at the 0.05 level, while for other variables there were no significant differences. The summary of current research is shown in Table 13.

Table 12. Effect on cost parameters

\begin{tabular}{|c|c|c|c|c|c|c|c|c|c|c|}
\hline & & & & & & & & Alph & $\begin{array}{r}\mathrm{P}=0 \\
\text { Cronba } \\
\mathrm{a}=0.8\end{array}$ & $\begin{array}{l}05 \\
\text { ch’s } \\
14252651\end{array}$ \\
\hline Variable & 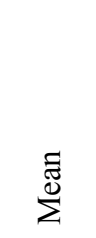 & 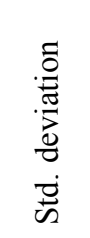 & 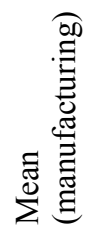 & 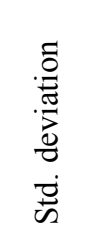 & 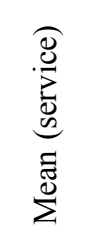 & 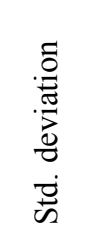 & 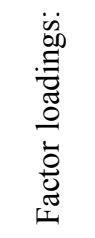 & 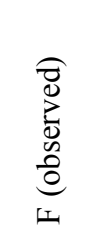 & 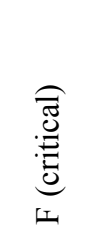 & 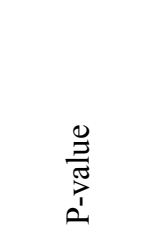 \\
\hline $\begin{array}{l}\text { Reduction in } \\
\text { manufacturing } \\
\text { cost }\end{array}$ & 4.065 & 1.114 & 4.023 & 1.002 & 3.842 & 1.344 & 0.676 & 0.555 & 2.380 & $\begin{array}{c}0.119 \\
\text { Accept H0 }\end{array}$ \\
\hline $\begin{array}{l}\text { Reduction } \\
\text { in inventory } \\
\text { carrying cost }\end{array}$ & 4.161 & 1.089 & 4.143 & 1.189 & 4.158 & 0.898 & 0.798 & 1.727 & 2.380 & $\begin{array}{c}0.212 \\
\text { Accept H0 }\end{array}$ \\
\hline $\begin{array}{l}\text { Reduction in } \\
\text { logistics cost. }\end{array}$ & 3.710 & 1.285 & 3.429 & 1.346 & 4.236 & 0.933 & 0.848 & 2.079 & 2.380 & $\begin{array}{c}0.008 \\
\text { Accept Ha }\end{array}$ \\
\hline
\end{tabular}

Table 13. Summary of current research

\begin{tabular}{cll}
\hline $\begin{array}{c}\text { Research } \\
\text { Issue }\end{array}$ & \multicolumn{1}{c}{ Author } & \multicolumn{1}{c}{ Issues discussed } \\
\hline \multirow{4}{*}{ Benefits } & Kapdia et al. $(2010)$ & $\begin{array}{l}\text { Supplier performance, faster and accurate } \\
\text { deliveries }\end{array}$ \\
\cline { 2 - 3 } & Zhu et al. $(2010)$ & Manufacturing flexibility \\
\cline { 2 - 3 } & Song and Dinwoodie (2008) & $\begin{array}{l}\text { Replenishment lead-times and customer service } \\
\text { under uncertain demands }\end{array}$ \\
\cline { 2 - 3 } & Tyan and Wee (2003) & Reduced stock outs \\
\cline { 2 - 3 } & Bookbinder et al. $(2010)$ & Reduced costs \\
\cline { 2 - 3 } & Santos et al. $(2010)$ & Improved profits \\
\hline
\end{tabular}


End of Table 13

\begin{tabular}{|c|c|c|}
\hline $\begin{array}{l}\text { Research } \\
\text { Issue }\end{array}$ & Author & Issues discussed \\
\hline \multirow{5}{*}{ Barriers } & Olorunniwo and Li (2010) & Issues related to information sharing \\
\hline & Pero et al. (2010) & Issues related to organizational barriers \\
\hline & Khan and Pillania (2008) & $\begin{array}{l}\text { Issues related to strategic changes in the firm, } \\
\text { changes in technology }\end{array}$ \\
\hline & Alves and Matos (2012). & Cultural issues \\
\hline & Tanskanen et al. (2009). & Problems related to technology \\
\hline \multirow{5}{*}{ Effects } & $\begin{array}{l}\text { Kuk (2004), Småros et al. } \\
\text { (2003) }\end{array}$ & Effects on quality parameters \\
\hline & $\begin{array}{l}\text { Rahman and } \mathrm{Wu}(2011) \text {, } \\
\text { Wilson (2007) }\end{array}$ & Effects on service parameters \\
\hline & Kuk (2004), Kim (2008) & Effects on cost parameters \\
\hline & Bookbinder et al. (2010) & Effects on cost parameters \\
\hline & $\begin{array}{l}\text { Sari (2008), Tyan and Wee } \\
(2003)\end{array}$ & Addressed the effects on productivity parameters \\
\hline \multirow{5}{*}{ Tools } & Pramatari (2007) & EDI/EDP \\
\hline & Pero et al. (2010) & Enterprise resource planning software \\
\hline & Olorunniwo and Li (2010) & Internet /Extranet for information sharing \\
\hline & Alves and Matos (2012). & EDI/EDP \\
\hline & Tanskanen et al. (2009). & RFID \\
\hline
\end{tabular}

\section{Conclusions}

This paper explores the operational issues, barriers, and effects of using VMI in Indian industries. The major contribution of the study is that it identifies sector differences in SMEs. Most VMI studies have taken place in developed countries, and there is a scarcity of empirical studies in developing countries. This study helps fill the lacuna by gathering empirical evidence using a sample of Indian industries. From a managerial viewpoint, the findings provide support for VMI adoption decisions and for decisions relating to operative VMI issues. The study addresses the research questions and found that the major effect is on order generation and the replenishment process. The recognizable difficulties for adoption were derived from organizational culture and technical fronts. Anarchy about information sharing is still predominant, and a major effect of VMI was found on cost and customer service.

Based on the survey results, it is concluded that for VMI adoption there are some similarities and differences in the manufacturing and service sector industries. It is found that VMI is in its early stages in India; hence, the basic form of VMI is applied. In developed countries, however, cooperative and synchronized forms of VMI are adopted, and the adoption decision is governed by dyad-level motivations that surround the implementation and are regulated by contextual factors (Kauremaa et al. 2009). For both sectors, coexistence of JIT was found to be a boon for smooth adoption. Although nu- 
merous IT tools are available for communication and information sharing, both sectors preferred communication through email. In developed countries, Internet and EDI/ERP are equally favored for electronic transfer. They have gone to the next level of adoption, and the need for segregation of upstream and downstream data transfer is in focus (Vigtil 2007). An exhaustive study on successful implementations is found in Alves and Matos (2012). Technological and cultural barriers were major roadblocks for both sectors. Alas et al. (2009) have also emphasized that cultural dimensions are connected with manufacturing strategies and choices. Similar results were found by Tanskanen et al. (2009). Their research revealed that the problems are mostly concerned with IT systems. The present study found that Indian industries have problems in understanding the concept. However, the activities carried out using supply chain software, operational benefits, strategic benefits, effect on productivity parameters, effect on quality parameters, effect on service parameters, and effect on cost parameters were different for both sectors. If we compare the effects, on the basis of ratings, it is observed that for Indian industries the major effect is on cost.

Adoption of VMI in some of the BRIC nations is seen in the literature with almost the same parameters that we considered in our study. For example, Siber do Brasil SA and many other companies implemented VMI, which made it possible to redirect the company goals toward the profit and their strategic objectives (Santos et al. 2011). VMI was adopted in Taiwanese grocery industries, which reduced the inventory cost for customers. Long-term partnerships, better resource planning, and efficient production scheduling were some of the results, which were confirmed in this study as well (Tyan, Wee 2003).

Information sharing needs a radical change in management thinking and style of working. It is more about cultural dimension and strategy (Alas et al. 2009). Hence, we believe that, although this study is carried out in an Indian context, the results may be used in other developing and Asian countries. The study has the usual limitations of survey research methodology. In this study only two sectors were considered, but in future studies four to six sectors could be taken with a larger sample.

\section{References}

Achabal, D. D.; Mcintyre, S. H.; Smith, S. A.; Kalyanam, K. 2000. Decision Support System for Vendor Managed Inventory, Journal of Retailing 76(4): 430-454.

http://dx.doi.org/10.1016/S0022-4359(00)00037-3

Alas, R.; Kraus, A.; Katrin, N. 2009. Manufacturing strategies and choices in cultural contexts, Journal of Business Economics and Management 10(4): 279-289.

http://dx.doi.org/10.3846/1611-1699.2009.10.279-289

Alves, M. C.; Matos, S. I. A. 2012. ERP adoption by public and private organizations - a comparative analysis of successful implementations, Journal of Business Economics and Management. http://dx.doi.org/10.3846/1611-1699.2009.10.279-289

Bhakoo, V.; Singh, P.; Sohal, A. 2012. Collaborative management of inventory in Australian hospital supply chains: practices and issues, Supply Chain Management: an International Journal, 17(2): 217-230. http://dx.doi.org/10.1108/13598541211212933 
Bookbinder, J. H., Gümüş, M., \& Jewkes, E. M. 2010. Calculating the benefits of vendor managed inventory in a manufacturer-retailer system. International Journal of Production Research, 48(19): 5549-5571. http://dx.doi.org/10.1080/00207540903095434

Borade, A. B.; Bansod, S. V. 2012. Study of Vendor Managed Inventory practices in Indian SMEs; Select Differences in Manufacturing and Service sector, International Journal of Logistics and Supply Management (in Press).

Borade, A. B; Kannan, G.; Bansod, S. V. 2012. Analytical hierarchy process based framework for VMI adoption, International Journal of Production Research.

http://dx.doi.org/10.1080/00207543.2011.650795

Borade, A. B; Bansod, S. V. 2010. Study of Vendor Managed Inventory practices in Indian industries, Journal of Manufacturing Technology Management 21(8): 1013-1038.

http://dx.doi.org/10.1108/17410381011086810

Danese, P.; Romano, P. 2011. Supply chain integration and efficiency performance: a study on the interactions between customer and supplier integration, Supply Chain Management: An International Journal, 16(4), 220-230. http://dx.doi.org/10.1108/13598541111139044

Disney, S. M.; Towill, D. R. 2006. A methodology for benchmarking replenishment-induced bullwhip, Supply Chain Management: an International Journal 11(2): 160-168.

http://dx.doi.org/10.1108/13598540610652555

Disney, S. M.; Towill, D. R. 2002a. A discrete transfer function model to determine the dynamic stability of a vendor managed inventory supply chain, International Journal of Production Research 40(1): 179-204. http://dx.doi.org/10.1016/S1366-5545(03)00014-0

Disney, S. M.; Towill, D. R. 2002b. A procedure for the optimization of the dynamic response of a vendor managed inventory system, Computers and Industrial Engineering 43(1/2): 27-58. http://dx.doi.org/10.1016/S0360-8352(02)00061-X

Dong, Y.; Xu, K.; Dresner, M. 2007. Environmental determinants of VMI adoption: an exploratory analysis, Transportation Research Part E 43(4): 355-69.

http://dx.doi.org/10.1016/j.tre.2006.01.004

Dorling, K.; Scott, J.; Deakins, E. 2005. An organization-level framework for the NZ food industry - its development and application, International Journal of Physical Distribution \& Logistics Management 35(10): 728-43. http://dx.doi.org/10.1108/09600030510634580

Govindan, K. 2013. Vendor managed inventory: a review based on dimensions, International Journal of Production Research 51(13): 3808-3835.

http://dx.doi.org/10.1080/00207543.2012.751511

Holweg, M.; Disney, S.; Holmström, J.; Småros, J. 2005. Supply chain collaboration: making sense of the strategy continuum, European Management Journal 23(2): 170-181.

http://dx.doi.org/10.1016/j.emj.2005.02.008

Kaipia, R.; Holmström, J.; Tanskanen, K. 2002. VMI: what are you losing if you let your customer place orders? Production Planning \& Control 13(1): 17-25.

http://dx.doi.org/10.1080/09537280110061539

Kannan, G.; Grigore, M. C.; Devika, K.; Senthilkumar, A. 2013. An analysis of the general benefits of a centralised VMI system based on the EOQ model, International Journal of Production Research 51(1): 172-188. http://dx.doi.org/10.1080/00207543.2011.653838

Kauremaa, J.; Småros, J.; Holmström, J. 2009. Patterns of vendor-managed inventory: findings from a multiple-case study, International Journal of Operations \& Production Management 29(11): 1109-1139. http://dx.doi.org/10.1108/01443570911000159

Kim, J. O.; Mueller, C. W. (Eds.). 1978. Factor analysis: statistical methods and practical issues, Vol. 14. Beverly Hills: Sage Publications. 
Khan, A.; Pillania, R. K. 2008. Strategic sourcing for supply chain agility and firms' performance: a study of Indian manufacturing sector, Management Decision 46(10): 1508-1530.

http://dx.doi.org/10.1108/00251740810920010

Kuk, G. 2004. Effectiveness of vendor-managed inventory in the electronics industry: determinants and outcomes, Information \& Management 41: 645-654.

http://dx.doi.org/10.1016/j.im.2003.08.002

Marquès, G.; Thierry, C.; Lamothe, J.; Gourc, D. 2010. A review of Vendor Managed Inventory (VMI): from concept to processes, Production Planning \& Control 21(6): 547-561.

http://dx.doi.org/10.1080/09537287.2010.488937

Olorunniwo, F. O.; Li, X. 2010. Information sharing and collaboration practices in reverse logistics, Supply Chain Management: an International Journal 15(6): 454-462.

http://dx.doi.org/10.1108/13598541011080437

Pero, M.; Abdelkafi, N.; Sianesi, A.; Blecker, T. 2010. A framework for the alignment of new product development and supply chains, Supply Chain Management: An International Journal 15(2): 115-128. http://dx.doi.org/10.1108/13598541011028723

Pramatari, K. 2007. Collaborative supply chain practices and evolving technological approaches, Supply Chain Management: an International Journal 12(3): 210-220.

http://dx.doi.org/10.1007/s13198-012-0114-9

Rahman, S.; Wu, Y. C. J. 2011. Logistics outsourcing in China: the manufacturer-cum-supplier perspective, Supply Chain Management: an International Journal 16(6): 462-473.

http://dx.doi.org/10.1108/13598541111171156

Santos, R. F.; Marins, F. A. S.; Alves, J. M.; Moellmann, A. H. 2011. A real application of the theory of constraints to supply, Brazilian Journal of Operations \& Production Management 7(2): $81-100$

Sari, K. 2008. On the benefits of CPFR and VMI: a comparative simulation study, International Journal of Production Economics 113(2): 575-586.

http://dx.doi.org/10.1016/j.ijpe.2007.10.021

Simoni, C.; Rabino, S.; Zanni, L. 2010. Italian and Indian gold and jewelry SMEs, marketing practices in the USA: a comparative case study, Journal of Small Business and Enterprise Development 17(3): 403-417. http://dx.doi.org/10.1108/14626001011068707

Småros, J.; Lehtonen, J. M.; Appelqvist, P.; Holmström, J. 2003. The impact of increasing demand visibility on production and inventory control efficiency, International Journal of Physical Distribution \& Logistics Management 33(4): 336-354.

http://dx.doi.org/10.1108/09600030310478801

Song, D.; Dinwoodie, J. 2008. Quantifying the effectiveness of VMI and integrated inventory management in a supply chain with uncertain lead-times and uncertain demands, Production Planning \& Control 19(6): 590-600. http://dx.doi.org/10.1080/09537280802420571

Stanger, S. H.; Wilding, R.; Yates, N.; Cotton, S. 2012. What drives perishable inventory management performance? Lessons learnt from the UK blood supply chain, Supply Chain Management: An International Journal 17(2): 107-123. http://dx.doi.org/ 10.1108/13598541211212861

Tanskanen, K.; Holmström, J.; Elfving, J.; Talvitie, U. 2009. Vendor managed-inventory (VMI) in construction, International Journal of Productivity and Performance Management 58(1): 29-40. http://dx.doi.org/10.1108/17410400910921065

Thron, T.; Nagy, G.; Wassan, N. 2006. The impact of various levels of collaborative engagement on global and individual supply chain performance, International Journal of Physical Distribution \& Logistics Management 36(8): 596-620. http://dx.doi.org/10.1108/09600030610702880

Tyan, J.; Wee, H. M. 2003. Vendor managed inventory: a survey of the Taiwanese grocery industry, Journal of Purchasing and Supply Management 9(1): 11-18.

http://dx.doi.org/10.1016/S0969-7012(02)00032-1 
Vigtil, A. 2007. Information exchange in vendor managed inventory, International Journal of Physical Distribution \& Logistics Management 37(2): 131-147.

http://dx.doi.org/10.1108/09600030710734848

Whipple, J. M.; Russell, D. 2007. Building supply chain collaboration: a typology of collaborative approaches, The International Journal of Logistics Management 18(2): 174-196.

http://dx.doi.org/10.1108/09574090710816922

Wilson, M. C. 2007. The impact of transportation disruptions on supply chain performance, Transportation Research Part E: Logistics and Transportation Review 43(4): 295-320. http://dx.doi.org/10.1016/j.tre.2005.09.008

Yu, H.; Zeng, A. Z.; Zhao, L. 2009. Analyzing the evolutionary stability of the vendor-managed inventory supply chains, Computers \& Industrial Engineering 56: 274-282.

http://dx.doi.org/10.1016/j.cie.2008.05.016

Zammori, F.; Braglia, M.; Frosolini, M. 2009. A standard agreement for vendor managed inventory, Strategic Outsourcing: an International Journal 2(2): 165-186.

http://dx.doi.org/10.1108/17538290910973376

Zhu, W.; Gavirneni S.; Kapuscinski, R. 2010. Periodic flexibility, information sharing, and supply chain performance, IIE Transactions 42: 173-187.

doi:http://dx.doi.org/10.1080/07408170903394314

Lixin SHEN, Associate Professor at Dalian Maritime University in Dalian, China, has published 30 papers in Journals and Conferences. Her research includes Logistics and e-commerce.

Kannan GOVINDAN, Associate Professor at University of Southern Denmark, Denmark, has published more than 80 papers in international journals and more than 60 papers in conferences. His current research includes logistics and supply chain management (SCM), Sustainable SCM, Corporate responsibility and environmental SCM.

Atul B. BORADE, Professor at Jawaharlal Darda Institute of Engineering and Technology, India, has published 25 papers in journals and conferences. His areas of interest are Manufacturing Management and Supply Chain Management.

Ali DIABAT, Associate Professor at Masdar Institute of Science and Technology, Abu Dhabi, UAE, has published 20 papers in journals and conferences. His areas of interest are Industrial Engineering and Supply Chain Management.

Devika KANNAN, graduate student at Aalborg University, Denmark, has published more than 25 papers in international journal and conferences. Her current research includes supply chain management (SCM), green supply chain management, and reverses logistics. 